\title{
PENGARUH PENERAPAN SISTEM MODERNISASI ADMINISTRASI PAJAK, KUALITAS PELAYANAN DAN PENGETAHUAN PPN TERHADAP KEPATUHAN WAJIB PAJAK DI DKI JAKARTA
}

\author{
Dessy Natalia Kumala Jaya
}

Fakultas Ekonomi Universitas Tarumanagara Jakarta

Email: Natalia_dessy91@yahoo.com

Masuk : 28-08-2018, revisi: 02-10-2019, diterima untuk diterbitkan : 30-10-2019

\begin{abstract}
ABSTRAK
Rendahnya kesadaran wajib pajak membayar dan melaporkan pajak telah menjadi masalah yang cukup penting bagi negara maju maupun berkembang dalam aspek pajak, Fakta menunjukkan bahwa tingkat kepatuhan wajib pajak di Indonesia masih sangat rendah dibanding dengan negara lain di Asia. Rendahnya kepatuhan wajib pajak dapat dilihat dan dikaji dari sisi kesadarannya melapor dan membayar pajak secara benar. Tujuan penelitian ini untuk menguji dan mengkaji pengaruh penerapan sistem modernisasi administrasi pajak, kualitas pelayanan, dan pengetahuan pajak pertambahan nilai terhadap kepatuhan wajib pajak di DKI Jakarta. Penelitian ini menggunakan metode penelitian kausal, dan data yang digunakan dalam penelitian ini adalah data primer. Teknik pengumpulan data yang dilakukan pada penelitian ini adalah dengan cara mengumpulkan data primer dengan metode survei melalui penyebaran kuesioner kepada setiap individu - individu yang berkerja di perusahaan yang merupakan Pengusaha Kena Pajak (PKP) yang berdomisili di provinsi DKI Jakarta. Hasil pengumpulan data primer tersebut diolah dengan menggunakan SmartPLS versi 3.2. Hasil dari penelitian ini menunjukkan bahwa sistem modernisasi administrasi pajak dan pengetahuan pajak pertambahan nilai berpengaruh signifikan terhadap kepatuhan wajib pajak. Sedangkan hubungan antara kualitas pelayanan pajak terhadap kepatuhan wajib pajak adalah berpengaruh tidak signifikan.
\end{abstract}

Kata Kunci: Penerapan Sistem Modernisasi Administrasi Pajak, Kualitas Pelayanan, Pengatahuan Pajak Pertambahan Nilai, Kepatuhan Wajib Pajak.

\begin{abstract}
The low awareness of taxpayers paying and reporting taxes has become an important issue for both developed and developing countries in the tax aspects. Facts show that taxpayer compliance rates in Indonesia are still very low compared to other countries in Asia. The low compliance of the taxpayer can be seen and reviewed from the side of his consciousness to report and pay taxes correctly. The purpose of this study was to examine and assess the effect of application of modernization system of tax administration, service quality, knowledge of value added tax on taxpayer compliance. The method used in this research is causative research. The data used in this study is the primary data. Data collection technique is done by collecting primary data in the form of questionnaires to individuals who work in taxable companies (PKP), domiciled in Jakarta. The primary data collection results were processed using SmartPLS version 3.2. The results of this study indicate that modernization system of tax administration and knowledge of value added tax have an influence on taxpayer compliance. While service quality have an insignificant effect on taxpayer compliance.
\end{abstract}

Keyword: Application of Modernization System of Tax Administration, Service Quality, Knowledge of Value Added Tax on Taxpayer Compliance.

\section{PENDAHULUAN}

\section{Latar Belakang}

Pajak juga merupakan salah satu sumber dana pemerintah yang memiliki peranan yang cukup besar untuk membiayai segala pengeluaran yang bersifat rutin maupun pengeluaran untuk pembangunan. Pemungutan pajak bersifat memaksa karena dilaksanakan berdasarkan undangundang. Penerimaan perpajakan mengalami peningkatan yang cukup signifikan baik secara nominal maupun secara persentase terhadap seluruh pendapatan negara. Oleh sebab itu pengelolaan penerimaan pajak harus dilakukan dengan baik, sistematis dan akurat. 
Kepatuhan pajak adalah keadaan wajib pajak dalam memenuhi hak dan kewajiban perpajakan.Sampai saat ini, tingkat kepatuhan wajib pajak dalam melaksanakan kewajiban perpajakan yang benar masih sangat rendah atau minim. Kepatuhan pajak masih merupakan masalah yang cukup besar untuk negara maju dan negara berkembang. Jika kepatuhan rendah, maka akan menimbulkan tindakan penghindaran pajak dan kelalaian pajak.

Modernisasi perpajakan dengan menggunakan teknologi berbasis e-system yang ada saat ini seperti e-billing, e-SPT, e-filling dan e-faktur diharapkan dapat meningkatkan mekanisme pengawasan yang lebih efektif dengan ditunjang penerapan kode etik pengawai Direktorat Jenderal Pajak untuk mengatur perilaku pengawai dalam melaksanakan tugas dan tanggung jawabnya. Tujuan diperbaruinya sistem pajak dan dengan ditambahnya sistem elektronik atau e-system diharapkan dapat meningkatkan kepatuhan pajak juga dapat meningkatkan kepercayaan masyarakat terhadap administrasi perpajakan, produktivitas pengawai pajak yang tinggi serta meningkatkan keefisienan dan keefektifan untuk mencapai target penerimaan pajak. Sedangkan tujuan dari penggunaan teknologi informasi dalam perpajakan itu sendiri adalah untuk menghemat waktu, memudahkan, dan akurat.

Target dari penyampaian SPT melalui e-Filing pada tahun 2016 adalah sebesar 7.000.000 SPT Tahunan. Pelaporan SPT tahunan melalui e-Filing ini adalah pelaporan SPT dalam bentuk dokumen elektronik yang dilakukan melalui situs djponline.pajak.go.id. Namun sampai dengan 31 Desember 2016 jumlah SPT yang dilaporkan sudah sebanyak 8.441.188 SPT yang berasal dari Wajib Pajak Orang Pribadi maupun Badan, baik yang melalui DJP Online maupun e-SPT yang disampaikan secara langsung ke kantor pajak. Pencapaian Indikator Kinerja Utama (IKU) ini merupakan hasil kerja sama serta kerja keras seluruh Direktorat dan unit vertikal di Direktorat Jenderal Pajak yang menjalankan sesuai dengan tugas dan kewenangannya masingmasing.

Kualitas pelayanan dapat menjadi keunggulan untuk memenuhi keinginan wajib pajak. Kualitas pelayanan dapat dinilai berdasarkan presepsi wajib pajak dengan membandingkan harapan wajib pajak saat menerima layanan dengan pengalaman yang terjadi sebenarnya atas layanan yangtelah diterima. Peningkatan kualitas pelayanan dapat dilakukan dengan cara meningkatan kualitas, kemampuan teknis pegawai di bidang perpajakan, perbaikan infrastruktur seperti perluasan Tempat Pelayanan Terpadu (TPT), penggunanan sistem informasi dan teknologi untuk memberikan kemudahan kepada wajib pajak dalam memenuhi kewajiban perpajakannya.

Salah satu faktor lainnya yang mempengaruhi kepatuhan pajak adalah pengetahuan wajib pajak akan tata cara melaksanakan kewajiban perpajakannya. Penguasaan terhadap peraturan perpajakan bagi wajib pajak akan meningkatkan kepatuhan kewajiban perpajakan. Wajib pajak akan berusaha menjalankan kewajibannya agar terhindar dari sanksi-sanksi yang berlaku dalam peraturan perpajakan. Semakin tinggi tingkat pendidikan atau pengetahuan wajib pajak, maka semakin mudah pula bagi wajib pajak untuk memahami peraturan perpajakan yang berlaku dan semakin mudah pula wajib pajak dalam memenuhi kewajiban perpajakannya.

Penelitian mengenai pengaruh modernisasi sistem administrasi perpajakan terhadap kepatuhan sudah banyak dilakukan diantaranya oleh Sarunan (2013) dengan hasil sistem administrasi modern yang ditandai dengan online payment, e-filing, e-SPT, e-registration dan sistem informasi DJP perpajakan berpengaruh positif dan signifikan terhadap kepatuhan wajib pajak pribadi dan badan yang berada di KPP Manado. Namun menurut Rahayu dan Lingga (2009) sistem administrasi perpajakan modern yang berfasilitas teknologi elektronik antara lain e- 
SPT, efiling, dan $e$ - registration tidak berpengaruh terhadap kepatuhan pajak. Penelitian ini bertujuan untuk menguji kekonsistenan hasil dari pengaruh $e$-filing, $e$-billing dan e-faktur jika dilakukan terhadap kepatuhan pajak pada wajib pajak di BMT se-Kabupaten Kudus. Penelitian mngenai pengaruh kualitas pelayanan pajak terhadap kepatuhan wajib pajak telah banyak dilakukan, antara lain penelitian yang dilakukan oleh Dharma dan Suardhana (2014) yang menyatakan bahwa kualitas pelayanan berpengaruh terhadap kepatuhan wajib pajak. Namun menurut penelitian yang dilakukan oleh Masruroh dan Zulaikha (2013) dijelaskan bahwa kualitas pelayanan tidak berpengaruh terhadap kepatuhan wajib pajak. Sedangkan penelitian mengenai pengaruh pengetahuan pajak juga telah banyak dilakukan, salah satunya penelitian yang dilakukan oleh Rahadi (2014) menyatakan bahwa pengetahuan dan pemahaman pajak berpengaruh positif terhadap kepatuhan wajib pajak. Namun menurut Suyapto dan Lasmana (2014) menyatakan bahwa pemahaman peraturan pajak tidak berpengaruh terhadap kepatuhan wajib pajak.

\section{Kajian Teori}

Theory of Planned Behavior (Teori Perilaku yang Direncanakan) dapat dianggap sebagai perluasan dari teori tindakan beralasan (Theory of Reasoned Action). Perbedaan TRA dengan TPB ialah adanya tambahan variabel kontrol perilaku yang dipersepsikan (perceived behavioral control

/ $P B C$ ). $P B C$ ditentukan oleh dua faktor yaitu perceived power (persepsi terhadap kekuasaan yang dimiliki untuk melakukan suatu perilaku) dan control beliefs (kepercayaan terhadap kemampuan dalam mengendalikan). Perceived Behavioral Control (PBC) mengindikasikan bahwa motivasi seseorang dipengaruhi oleh bagaimana ia mempersepsikan tingkat kemudahan atau kesulitan untuk menampilkan perilaku tertentu. Asumsi utama dari teori tindakan beralasan (TPB) dan teori perilaku yang direncanakan (TRA) adalah individu yang rasional dalam mempertimbangkan tindakan mereka serta implikasi dari tindakan mereka dalam pengambilan keputusan. Rasionalitas dalam pengambilan keputusan mengasumsikan bahwa keputusan tersebut dibuat di bawah ketidakpastian, (Basu 1996; Eppen et al. 1998). Menurut Basu 1996; Bazerman 2002; Eppen et al. 1998 "Pembuatan keputusan rasional menyiratkan bahwa diharapkan adanya hasil yang optimal atau unit pengambilan keputusan menyadari semua dampak dan konsekuensi". Dalam penelitian ini, penulis menggunakan Theory of Planned Behavior karena cukup relevan untuk menjelaskan bahwa perilaku wajib pajak dalam menjalankan kepatuhan akan perpajakannya dipengaruhi oleh intensi dan intensi datang dari norma subyektif, sikap, dan kontrol perilaku yang dipersepsikan. 
Berikut ini merupakan bagan Theory of Planned Behavior:

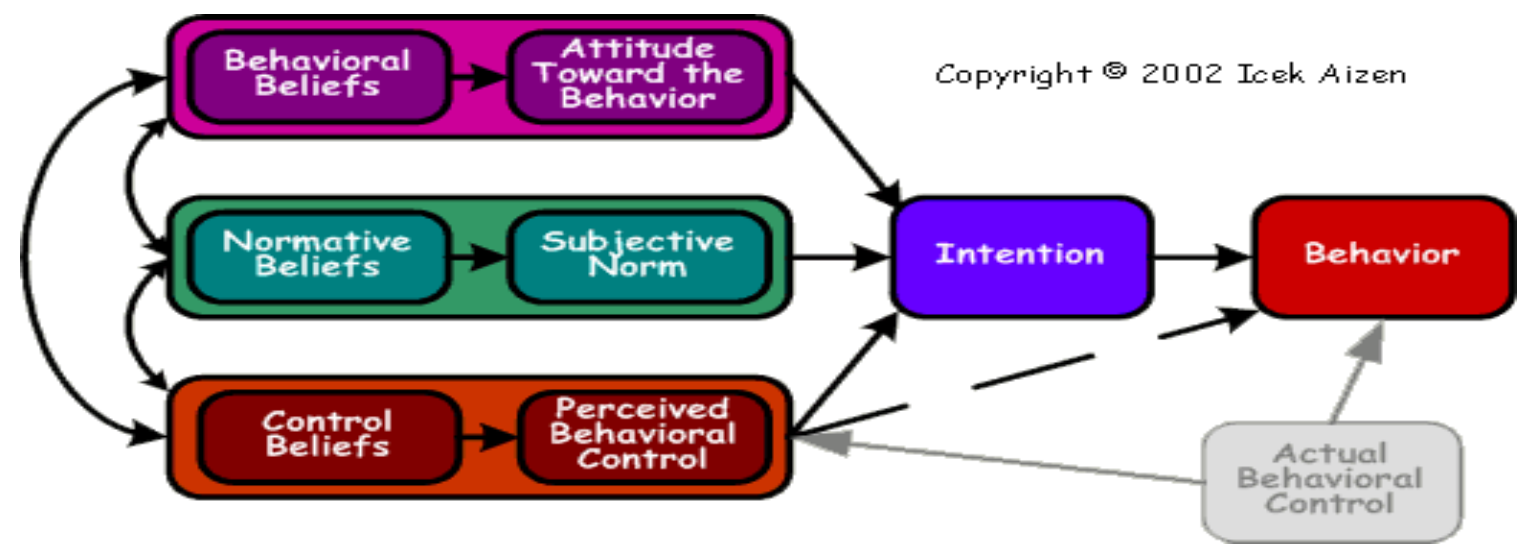

Menurut Robbins (1996), Teori atribusi menerangkan apabila individu-individu mengamati perilaku seseorang, maka mereka akan mencoba untuk menentukan apakah itu ditimbulkan secara internal atau eksternal. Atribusi merupakan proses dalam menarik kesimpulan mengenai faktor- faktor yang mempengaruhi perilaku orang lain. Atribusi Internal adalah perilaku yang disebabkan dari internal yaitu perilaku yang diyakini berada di bawah kendali pribadi individu itu sendiri atau yang berasal dari faktor internal seperti kepribadian, kesadaran, serta kemampuan. Sedangkan Atribusi Eksternal merupakan perilaku yang disebabkan karena faktor eksternal, yaitu perilaku yang dipengaruhi dari luar seperti peralatan atau pengaruh sosial dari orang lain, artinya individu akan terpaksa berperilaku karena situasinya. Dalam penelitian ini, penulis menggunakan Teori Atribusi ini karena relevan untuk menjelaskan bahwa wajib pajak dalam menjalankan kepatuhan perpajakannya dipengaruhi oleh kondisi internal dan juga kondisi eksternal.

Model TAM diadopsi dari model Theory of Reasoned Action (TRA) yaitu teori tindakan beralasan yang dikembangkan oleh Fishbein dan Ajzen (1975). Technology Acceptance Model (TAM) digunakan untuk memprediksi penerimaan pengguna terhadap teknologi yang berdasarkan dua variabel, yaitu persepsi kegunaan (perceived usefulness) dan persepsi kemudahan penggunaan (perceived ease of use). Persepsi kegunaan (perceived usefulness) adalah tingkat kepercayaan pengguna yaitu bahwa dengan menggunakan sistem maka dapat meningkatkan kinerja pengguna tersebut. Sedangkan persepsi kemudahan penggunaan (perceived ease of use) adalah tingkat kepercayaan pengguna bahwa sistem dapat digunakan dengan mudah dan dapat dipelajari sendiri atau otodidak.

Pengertian administrasi pajak secara umum adalah penatausahaan dan pelayanan terhadap hak dan kewajiban wajib pajak, baik penatausahaan atau pelayanan tersebut dilakukan di kantor pajak maupun di kantor Wajib Pajak itu sendiri. Secara umum, administrasi pajak merupakan salah satu kunci keberhasilan dalam suatu kebijakan pajak. Reformasi administrasi pajak idealnya merupakan instrumen untuk meningkatkan kepercayaan masyarakat, meningkatkan kepatuhan sukarela Wajib Pajak serta meningkatkan integritas aparat pajak. Dengan adanya system administrasi pajak yang baik, diharapkan pemerintah mampu mengoptimalkan realisasi penerimaan pajak dan meningkatkan kepatuhan perpajakan. Gunadi (2004), menekankan pentingnya peran administrasi perpajakan menuju kondisi terkini, dan pengalaman di berbagai negara berkembang. Kebijakan perpajakan (tax policy) dianggap baik, adil dan efisien dapat saja kurang berhasil menghasilkan penerimaan atau mencapai sasaran lainnya karena administrasi perpajakan tidak mampu untuk melaksanakannya. Gunadi juga berpendapat bahwa "administrasi perpajakan dituntut untuk bersifat dinamik sebagai upaya peningkatan penerapan kebijakan perpajakan yang efektif. 
Salah satu model pendekatan yang dapat dan biasa sering digunakan untuk menilai kualitas pelayanan adalah model Service Quality (ServQual). Menurut American Society for Quality Control, Kualitas dapat didefinisikan sebagai keseluruhan ciri-ciri dan karakteristik dari suatu produk atau jasa dalam hal kemampuannya untuk memenuhi kebutuhan yang telah ditentukan dan bersifat laten. Kualitas pelayanan pajak merupakan salah satu bentuk upaya yang dapat dilakukan untuk meningkatkan kepatuhan wajib pajak. Peningkatan kualitas pelayanan pajak diharapkan dapat memberikan kepuasan tersendiri bagi wajib pajak, dengan demikian pelayanan yang baik akan mendorong wajib pajak dalam melaksanakan kewajiban perpajakannya sehingga pelayanan pajak yang baik mempengaruhi meningkatnya kepatuhan wajib pajak. Menurut Boediono (2003 :

60 ) pelayanan adalah suatu proses besutan kepada orang lain dengan cara tertentu yang memerlukan kepekaan dan hubungan interpersonal agar terciptanya kepuasan dan keberhasilan sedangkan berkenaan dengan kegiatan pemerintahan. Terdapat lima dimensi dalam instrumen Service Quality (ServQual) yang dikembangkan Dikembangkan oleh Parasurahman et al dalam Najib (2012:60). antara lain Bukti Fisik, Keandalan, Daya Tanggap, Keyakinan, Empati.

Di Indonesia, pemahaman dan pengetahuan wajib pajak mengenai aturan perpajakan dapat dikatakan masih rendah. Pengertian pengetahuan pajak itu sendiri adalah kemampuan wajib pajak dalam mengetahui peraturan pajak yang benar, baik itu soal tarif yang berdasarkan undang-undang maupun manfaat pajak yang secara tidak langsung dapat dirasakan bersama. Semakin tinggi tingkat pendidikan atau pengetahuan wajib pajak, maka semakin mudah bagi wajib pajak untuk memahami peraturan perpajakan yang berlaku dan semakin mudah pula wajib pajak dalam memenuhi kewajiban perpajakannya memahami peraturan perpajakan yang berlaku dan semakin mudah pula wajib pajak dalam memenuhi kewajiban perpajakannya. Pemahaman dan pengetahuan wajib pajak dapat dikatakan masih rendah dapat dilihat dari masih adanya wajib pajak yang belum memahami pengisian Surat Pemberitahuan (SPT) Tahunan dan masih ada pula wajib pajak yang melakukan kesalahan dalam pengisian Surat Pemberitahuan tahunan. Hal ini menjadi tugas ekstra bagi Direktorat Jenderal Pajak maupun Kantor Pelayanan Pajak untuk dapat mensosialisasikan aturan-aturan pajak serta memberikan penyuluhan mengenai perpajakan seperti penghitungan pajak yang benar, waktu pelaporan pajak yang tepat dan aturan-aturan pajak lainnya sehingga wajib pajak mempunyai pengetahuan perpajakan.

Kepatuhan perpajakan menurut Devano dan Rahayu (2006) merupakan ketaatan, tunduk dan patuh melaksanakan ketentuan perpajakan. Pengertian kepatuhan pajak menurut Rahman (2010) adalah "suatu keadaan dimana wajib pajak memenuhi semua kewajiban perpajakan dan melaksanakan hak perpajakannya". Kepatuhan Wajib Pajak dapat diidentifikasi melalui Wajib Pajak itu sendiri diantaranya kepatuhan mendaftarkan diri, kepatuhan dalam menghitung dan membayar pajak terhutang, kepatuhan melaporkan Surat Pemberitahuan (SPT) tepat waktu, serta kebenaran dalam membayar angsuran Pajak Penghasilan (PPh). 


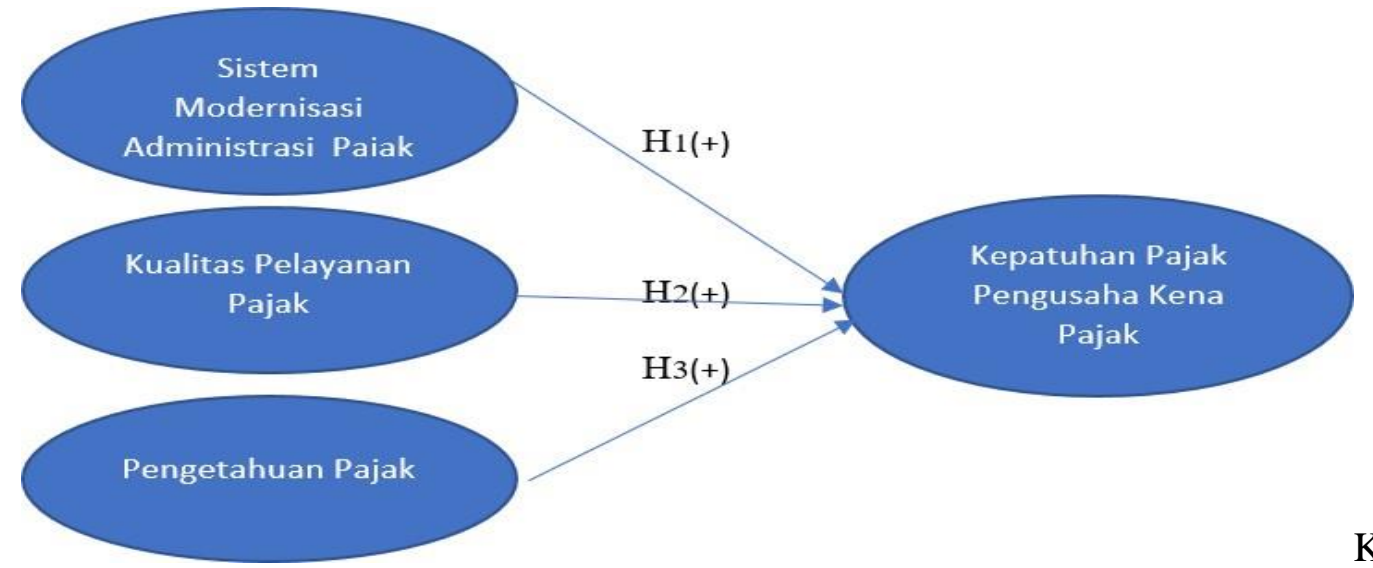

Pemikiran dalam penelitian ini dapat digambarkan sebagai berikut:

Kerangka

Hipotesis yang dibangun dari model di atas adalah, sebagai berikut:

H1: Penerapan Sistem Modernisasi Administrasi Perpajakan berpengaruh positif terhadap Kepatuhan Wajib Pajak di DKI Jakarta.

H2: Kualitas Pelayanan Pajak berpengaruh positif terhadap Kepatuhan Wajib Pajak di DKI Jakarta.

H3: Pengetahuan Pajak Pertambahan Nilai berpengaruh positif terhadap Kepatuhan Wajib Pajak di DKI Jakarta.

\section{METODE PENELITIAN}

Penelitian ini merupakan adaptasi dari penelitian sebelumnya yang dilakukan oleh Christin (2017). Ada beberapa penyesuaian yang dilakukan agar penelitian menjadi relevan dengan kondisi objek penelitian antara lain: (a) Penambahan variabel independen yang diteliti yaitu kualitas pelayanan pajak dan pengetahuan pajak, (b) Pengurangan variabel independen yang diteliti yaitu kemampuan menggunakan internet sebagai variabel moderating, (c) Perubahan variabel independen yaitu dari pengaruh penerapan e-faktur dan E-SPT PPN menjadi pengaruh penerapan sistem modernisasi administrasi pajak.

Objek dalam penelitian ini adalah Wajib Pajak yang terdaftar di Kantor Pelayanan Pajak wilayah provinsi DKI Jakarta khususnya wajib pajak yang sudah dikukuhkan sebagai Pengusaha Kena Pajak. Metode atau teknik pemilihan sampel yang digunakan adalah metode simple random sampling. Metode simple random sampling yaitu metode pemilihan secara acak tanpa dilakukan pengelompokan terlebih dahulu.

Variabel yang digunakan dalam penelitian ini terdiri dari Sistem Modernisasi Administrasi Pajak, Kualitas Pelayanan Pajak, Pengetahuan Pajak, Kepatuhan Pajak Pengusaha Kena Pajak. Variabel Indikator adalah varibel yang dapat diukur secara langsung. Variabel Laten yang akan diteliti memiliki Variable Indikator diantaranya: (1) Variabel Laten Sistem Modernisasi Administrasi Pajak akan terdiri dari 5 Variabel Indikator dan disingkat menjadi MODERN1 sampai dengan MODERN5, (2) Variabel Laten Kualitas Pelayanan Pajak akan terdiri dari 5 Variabel Indikator dan disingkat menjadi KUALITAS1 sampai dengan KUALITAS5, (3) Variabel Laten Pengetahuan Pajak akan terdiri dari 5 Variabel Indikator dan disingkat menjadi TAHU1 


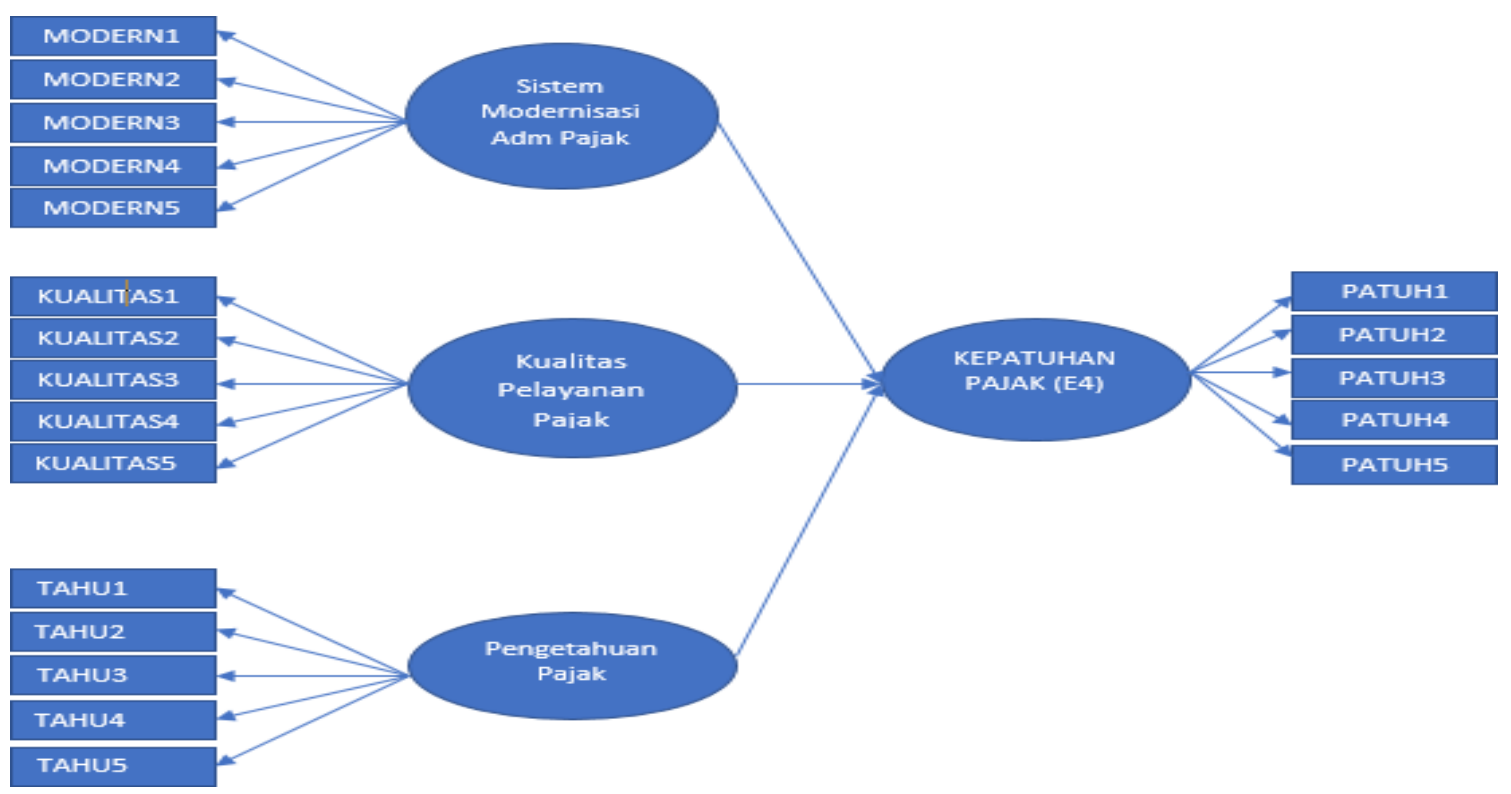

sampai dengan TAHU5, (4) Variabel Laten Kepatuhan Pajak Pengusaha Kena Pajak akan terdiri dari 5 Variabel Indikator dan disingkat menjadi PATUH1 sampai dengan PATUH5. Penulis menyebarkan kuesioner kepada wajib pajak yang memiliki kualifikasi pengusaha kena pajak, dalam kuesioner tersebut penulis menentukan 4 buah kelompok jawaban dengan Skala Likert adalah yaitu Sangat Tidak Setuju (STS), Tidak Setuju (TS), Setuju (S), Sangat Setuju (SS).

Keterangan Varibel Indikator sebagai berikut:

MODERN1:Sistem Administrasi modern digunakan untuk kemudahan pemenuhan kewajiban.

MODERN2: Pembayaran pajak melalui online.

MODERN3: Pelaporan secara elektronik.

MODERN4: Complaint center memberikan kemudahan bagi

WP. MODERN5: Reformasi pajak memudahkan petugas pajak.

KUALITAS1: Keandalan (Reliability).

KUALITAS2 : Bukti Langsung (Tangible).

KUALITAS3 : Ketanggapan

(Responsiveness). KUALITAS4 : Jaminan

(Assurance).

KUALITAS5 : Empati (Emphaty).

TAHU1 : Pengetahuan mengenai sistem perpajakan

TAHU2 : Pengetahuan mengenai ketentuan umum dan tata cara perpajakan

TAHU3 : Pengetahuan mengenai sumber dana pajak.

TAHU4 : Pengetahuan mengenai fungsi perpajakan

TAHU5: Pengetahuan mengenai ketentuan umum dan tata cara perpajakan

PATUH1: Pendaftaran NPWP

PATUH2: Mengisi SPT sesuai dengan ketentuan yang

berlaku. PATUH3: Melakukan perhitungan pajak dengan

benar.

PATUH4 : Melakukan pembayaran tepat waktu.

PATUH5 : Melakukan pelaporan pajak tepat

waktu. 


\section{HASIL DAN PEMBAHASAN}

Jenis data yang dianalisis dalam penelitian ini adalah data primer yang dilakukan dengan cara mengumpulkan kuisioner dari responden dan menggunakan data dari hasil ringkasan kuesioner yang disebar. Kuesioner yang dibagikan kepada setiap responden berisi 20 butir pertanyaan yang terkait dengan setiap variabel yang ada dalam penelitian ini. 5 pertanyaan pertama merupakan pertanyaan yang terkait dengan variabel modernisasi sistem administrasi pajak (X1), 5 pertanyaan berikutnya merupakan pertanyaan yang terkait dengan variabel kualitas pelayanan pajak (X2), 5 pertanyaan selanjutnya merupakan pertanyaan yang terkait dengan variabel pengetahuan pajak (X3) dan 5 pertanyaan terakhir merupakan pertanyaan yang terkait dengan kepatuhan wajib pajak (Y). Kuesioner yang disebarkan pada karyawankaryawan yang bekerja pada perusahaan yang telah dikukuhkan sebagai pengusaha kena pajak (PKP) yang berdomisili di Jakarta dalam penelitian ini sebanyak 150 kuesioner. Dari total tersebut yang dikembalikan sebanyak 100 kuesioner. Kuesioner yang telah diisi dan dikembalikan digunakan sebagai data dalam penelitian ini.

Berdasarkan data yang dikumpulkan oleh peneliti, telah didapatkan data jumlah responden menurut jenis kelaminnya yaitu 35 orang berjenis kelamin pria dengan persentase sebesar $35 \%$ dan 65 orang berjenis kelamin wanita dengan persentase $65 \%$. data jumlah responden yang didapat menurut umurnya yaitu 43 orang berumur kisaran 21-30 tahun dengan persentase sebesar $43 \%, 36$ orang berumur kisaran 31-40 tahun dengan persentase sebesar 36\%, 16 orang berumur kisaran 41- 50 tahun dengan persentase sebesar $16 \%$ dan 5 orang berumur diatas 50 tahun dengan persentase 5\%. Berdasarkan data yang dikumpulkan oleh peneliti, telah didapatkan data jumlah responden menurut pendidikannya yaitu 64 orang berpendidikan Sarjana (S1) dengan persentase sebesar 64\%, 20 orang berpendidikan SMA dengan persentase sebesar 20\%, 11 orang berpendidikan Magister (S2) dengan persentase sebesar $11 \%$ dan 5 orang berpendidikan Doktor (S3) dengan persentase 5\%. Data jumlah responden yang memiliki NPWP yaitu sebanyak 100 orang atau sebesar $100 \%$.

Uji validitas konvergen dalam PLS dengan indikator reflektif dinilai berdasarkan korelasi antara skor item/skor komponen dengan skor konstruk (loading factor) indikator - indikator yang mengukur konstruk tersebut. Dengan demikian, semakin tinggi nilai loading factor, semakin penting peranan loading dalam menginterpretaskan matrik faktor. Sedangkan Rule of thumb yang digunakan untuk validitas konvergen adalah outer loading $>0.7$ dan Average Variance Extracted (AVE) > 0.5 (Chin, 1995).

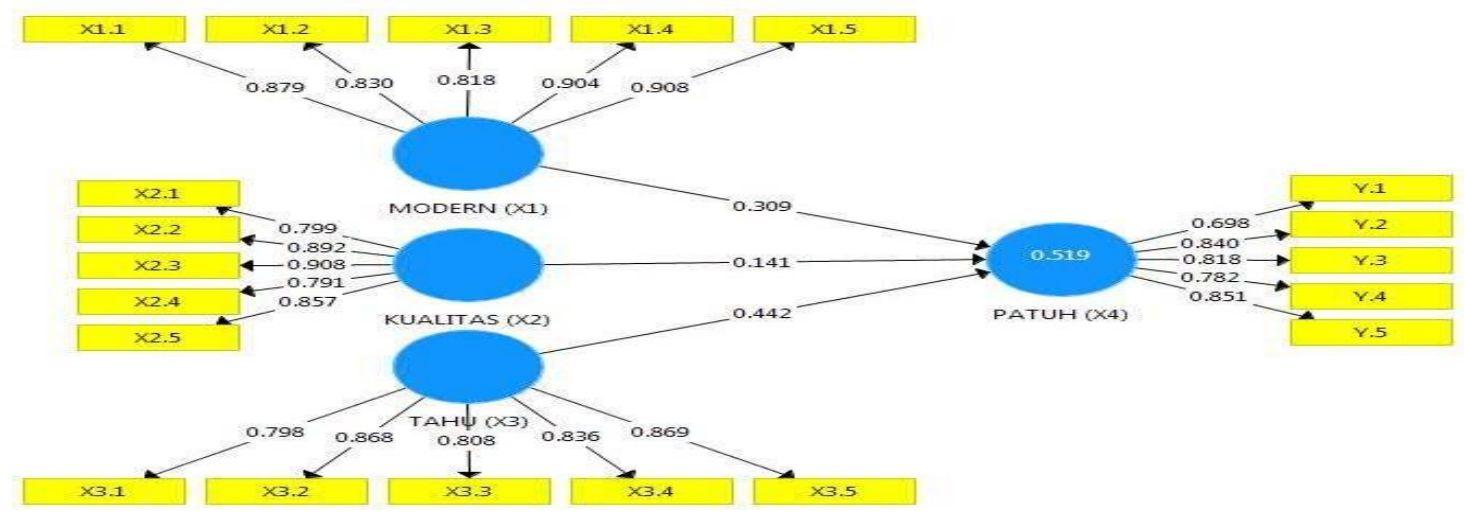

Hasil Outer Loading Factor 


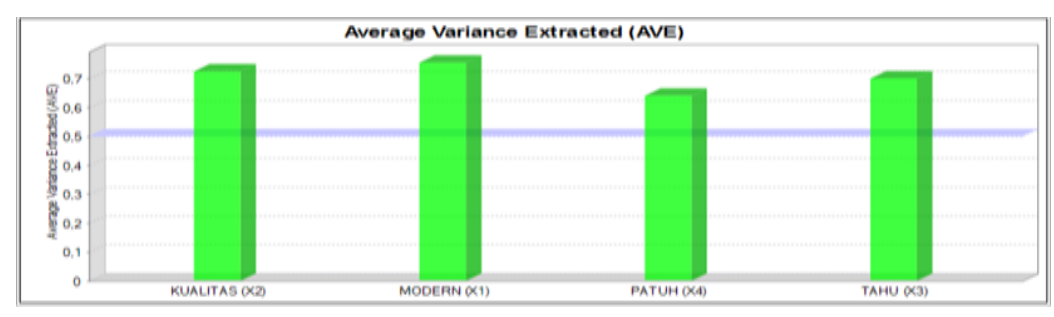

Hasil Average Variance Extracted (AVE)

Berdasarkan hasil pengelolahan data yang dilakukan oleh peneliti menunjukan hasil bahwa untuk Outer Loading Factor semua nilainya diatas 0.70, terkecuali salah satu indikator dari variabel kepatuhan wajib pajak yang nilainya 0.698. Namun menurut Hair (dalam Sholihin, 2013) jika loading berada diantara 0.40 - 0.70 dapat dipertimbangkan untuk tetap dipertahankan. Indikator dengan loading kecil dapat tetap dipertahankan karena mempunyai kontribusi pada validitas isi konstruk yang dapat dilihat bahwa varibel kepatuhan pajak memiliki nilai AVE sebesar 0.640 (> 0.50) dan nilai composite reliability sebesar 0.898 (>0.70) jadi peneliti tetap akan mempertahakan idikator ini.

Validitas diskriminan terjadi apabila dua instrumen berbeda yang mengukur dua konstruk yang diprediksi tidak berkorelasi menghasilkan skor yang memang tidak berkorelasi (Hartono, 2008 : 64). Berdasarkan hasil pengujian validitas diskriminan ditunjukan bahwa semua indikator dalam sebuah variabel bernilai diatas 0.70 tetapi untuk salah satu indikator kepatuhan wajib pajak ada yang bernilai dibawah 0.70 yaitu 0.698. Namun peneliti tetap mempertahankan indikator ini dikarenakan nilai cross loading indikator tersebut lebih besar terhadap variabel kepatuhan wajib pajak dibandingkan dengan hasil cross loading ke variabel lain. Dengan kata lain, seluruh indikator di atas telah memenuhi kriteria validitas diskriminan dan peneliti dapat melanjutkan ke tahap proses pengujian berikutnya.

Uji reliabilitas dalam PLS dapat menggunakan dua metode yaitu Cronbach's alpha dan Composite Reliability. Cronbach's alpha digunakan untuk mengukur batas bawah nilai reliabilitas suatu konstruk. Untuk dapat dikatakan reliabel maka nilai dari Cronbach's alpha harus > 0.6, dan untuk Composite Reliability digunakan untuk mengukur nilai sesungguhnya reliabilitas suatu konstruk. Composite Reliability dapat dikatakan reliabel jika nilainya $>0.70$. Berdasarkan hasil pengujian reliabilitas menunjukan Nilai Cronbach's Alpha lebih besar dari 0.6 dimana modernisasi sistem administrasi pajak (X1) menghasilkan 0.919, kualitas pelayanan pajak (X2) menghasilkan 0.905, pengetahuan pajak (X3) menghasilkan 0.892 dan kepatuhan wajib pajak (Y) menghasilkan 0.858. Dan untuk nilai Composite Reliability lebih besar dari 0.7 dimana modernisasi sistem administrasi pajak (X1) menghasilakan 0.939, kualitas pelayanan pajak (X2) menghasilkan 0.929, pengetahuan pajak (X3) menghasilkan 0.921 dan kepatuhan wajib pajak (Y) menghasilkan 0.898. Semua varuiabel ini sudah memenuhi syarat dalam pengujian reliabilitas.

Model Struktural dalam PLS dapat dievaluasi dengan menggunakan $\mathrm{R}^{2}$ untuk konstruk dependen. Nilai $\mathrm{R}^{2}$ digunakan untuk mengukur tingkat variasi pada perubahan variabel independen terhadap variabel dependen. Semakin tinggi hasil nilai $\mathrm{R}^{2}$ berarti semakin baik model prediksi dari model penelitian yang diajukan. Berdasarkan analisis yang dilakukan peneliti, diperoleh angka $\mathrm{R}^{2}$ ( $\mathrm{R}$ square) sebesar 0,519 (51,9\%) hal ini menunjukkan bahwa persentase sumbangan pengaruh variabel independen yaitu modernisasi sistem administrasi pajak, kualitas pajak dan pengetahuan pajak terhadap kepatuhan wajib pajak sebesar $51,9 \%$ sedangkan $48,1 \%$ dipengaruhi oleh variabel lain yang tidak dimasukkan dalam model penelitian ini. 


\begin{tabular}{|c|c|c|c|c|c|c|}
\hline No & Variabel & Original Sampel (0) & $\begin{array}{l}\text { TStatistik } \\
\text { (0/STDEV) }\end{array}$ & TTabel & P Value & Pengaruh \\
\hline 1 & $\begin{array}{l}\text { Modernisasi Sistem Administrasi } \\
\text { Pajak (X1) }\end{array}$ & 0.309 & 3.980 & 1.983 & 0.000 & Berpengaruh Signifikan \\
\hline 2 & Kualitas Pelayanan Pajak (X2) & 0.141 & 1.816 & 1.983 & 0.069 & Berpengaruh Tidak Signifikan \\
\hline 3 & Pengetahuan Pajak (X3) & 0.442 & 5.242 & 1.983 & 0.000 & Berpengaruh Signifikan \\
\hline
\end{tabular}

Berdasarkan hasil perhitungan uji struktural model (Inner Model), dapat dilihat bahwa untuk variabel kualitas pelayanan pajak memiliki nilai $p$-value sebesar $0.069>0.05$ dan nilai $t$ statistic sebesar $1.816<1.983$, hasil ini menunjukan bahwa variabel kualitas pelayanan pajak berpengaruh tidak signifikan terhadap kepatuhan wajib pajak. Dan untuk variabel modernisasi sistem administrasi pajak dan pengetahuan pajak memiliki nilai $p$-value sebesar $0.000<0.05$ dan $t$ - statistic sebesar $3.980>1.983$ dan $5.242>1.983$ menunjukan bahwa variabel modernisasi administrasi pajak juga pengetahuan pajak memiliki pengaruh signifikan terhadap kepatuhan wajib pajak. Karena nilai $p$-value pada variabel kualitas pelayanan pajak lebih besar dibandingkan tingkat signifikansi yang digunakan dalam penelitian ini, yaitu sebesar 0,05 dan untuk $t$-statistic variabel kualitas pelayanan pajak lebih kecil dibandingkan tingkat signifikansi yang digunakan dalam penelitian ini, yaitu 1.983 maka $\mathrm{H}_{2}$ dalam penelitian ini ditolak yang berarti variabel kualitas pelayanan pajak berpengaruh tidak signifikan terhadap kepatuhan wajib pajak.

\section{KESIMPULAN DAN SARAN}

Hasil pengujian hipotesis pertama menunjukan bahwa variabel sistem modernisasi administrasi pajak berpengaruh signifikan terhadap kepatuhan wajib pajak di DKI Jakarta $(<0,05)$. Hal tersebut dikarenakan bahwa semakin modern sistem administrasi perpajakan, akan membuat wajib pajak lebih mudah dalam melaksanakan kewajiban perpajakannya, sehingga kepatuhan perpajakan akan semakin meningkat. Hasil pengujian hipotesis kedua menunjukan bahwa variabel kualitas pelayanan pajak berpengaruh tidak signifikan terhadap kepatuhan wajib pajak di DKI Jakarta(>0,05). Hal ini disebabkan karena kualitas pelayanan dari aparat pajak belum dapat memenuhi atau melebihi harapan wajib pajak. Adanya oknum-oknum yang menyalahgunakan dana pajak juga membuat kepercayaan wajib pajak kepada aparat pajak menjadi turun. Hal ini tentu dapat mengakibatkan citra pelayanan aparat pajak menjadi negatif di mata wajib pajak yang berdampak pada minimnya kepatuhan wajib pajak dalam membayar dan melaporkan pajaknya. Hasil pengujian hipotesis ketiga menunjukan bahwa variabel pengetahuan pajak atas pajak pertambahan nilai berpengaruh signifikan terhadap kepatuhan wajib pajak di DKI Jakarta $(<0,05)$. Hasil penelitian ini membuktikan bahwa semakin tinggi pengetahuan wajib pajak mengenai tata cara umum perpajakan, seperti pencatatan, pembayaran, pelaporan, dan sanksi yang berlaku, akan membuat wajib pajak semakin taat dalam melaksanakan kewajiban perpajakannya sehingga kepatuhan wajib pajak meningkat.

Berdasarkan hasil pengolahan dan analisis data yang telah dilakukan, maka dapat disimpulkan bahwa sistem moderanisasi administrasi pajak dan juga pengetahuan pajak memiliki pengaruh positif terhadap kepatuhan wajib pajak, sedangkan kualitas pelayanan pajak memiliki pengaruh negative terhadap kepatuhan wajib pajak.

Keterbatasan dari penelitian ini dikarenakan hanya dilakukan pada perusahaan yang memiliki kualifikasi pengusaha kena pajak (PKP) di Jakarta, sehingga hasil penelitian tidak dapat mencerminkan kondisi pada PKP diluar Jakarta dan juga kepatuhan wajib pajak dalam penelitian ini hanya ditinjau dari tiga variabel yaitu independensi yaitu, sistem modernisasi administrasi perpajakan, kualitas pelayanan pajak dan pengetahuan pajak. 
Berdasarkan kesimpulan dan keterbatasan dalam penelitian seperti yang telah diuraikan di atas, maka saran yang dapat peneliti berikan untuk penelitian selanjutnya adalah sebagai berikut: (1) Bagi penelitian selanjutnya diharapkan dapat memperluas cakupan atas objek penelitian yang akan diteliti sehingga tidak hanya terbatas pada responden yang bekerja pada perusahaan yang memiliki kualifikasi pengusaha kena pajak yang berdomisili di Jakarta saja namun bisa dari beberapa daerah lainnya, (2) Dalam penelitian ini kepatuhan wajib pajak hanya ditinjau dari aspek modernisasi administrasi pajak, kualitas pelayanan pajak dan pengetahuan pajak. Sementara masih terdapat banyak aspek lain yang dapat mempengaruhi kepatuhan wajib pajak PPN, (3) Dalam penelitian selanjutnya sebaiknya dapat menggembangkan model penelitian yang lebih kompleks contohnya dengan memasukkan variabel kontrol atau variabel moderating dalam model penelitian.

\section{REFERENSI}

Ajzen, I. (1991). The theory of planned behavior. Organizational Behavior and Human Decision Processes, 50, p. 179-211.

Arisma, Putri Eka. 2015. Pengaruh Sanksi Perpajakan, Kesadaran Perpajakan dan Kualitas Pelayanan Terhadap Kepatuhan wajib Pajak Badan di kota Metro (Studi Kasus di Kantor Pelayanan Pajak Pratama Metro).

Artiningsih. 2013. Pengaruh Kesadaran Wajib Pajak Badan dan Pelayanan Perpajakan terhadap Kepatuhan Wajib Pajak di Kantor Pelayanan Pajak Pratama Sleman. Skripsi. Jurusan Akuntansi Fakultas Ekonomi Universitas Negeri Yogyakarta.

Ary Kurniawan 2015 "Penerapan E-Faktur Pajak Terhadap Pengusaha Kena pajak di Kota Surabaya" Laporan Penelitian Fakultas Ekonomi Universitas Airlangga.

Ayunda, Winda Putri, Nur Azlina, dan Azhari S. 2015. Pengaruh Sanksi Perpajakan, Pengetahuan Pajak, Sikap Wajib Pajak, Dan Tingkat Ekonomi Terhadap Kepatuhan Wajib Pajak Dalam Membayar Pajak Bumi dan Bangunan Dengan Kontrol Petugas Kelurahan Sebagai Variabel Moderating di Kota Pekanbaru. Jom FEKON. Vol. 2, No. 2. Oktober 2015.

Christin, Lena. 2017. Pengaruh Penerapan E-Faktur dan E-SPT Terhadap Kepatuhan Perpajakan Pengusaha Kena Pajak Dengan Kemampuan Menggunakan Internet Sebagai Variabel Moderating. ISSN: 2355-9993. Media Akuntansi Perpajakan. Vol.2, No.1, 2017, Hal 35-44.

Dharma, Gede Pani Esa dan Ketut Alit Suardana. 2014. Pengaruh Kesadaran Wajib Pajak, Sosialisasi Perpajakan, Kualitas Pelayanan Pada Kepatuhan Wajib Pajak. E-Jurnal Akuntansi Universitas Udayana. ISSN: 2302-8556. Hal 340-353.

Ita Salsalina Lingga 2015 "Pengaruh Sosialisasi dan Penerapan E-Faktur PPN terhadap Persepsi Pengusaha Kena Pajak" Laporan Penelitian Fakultas Ekonomi Atma Jaya.

Ihsan, Muchsin. 2014. Pengaruh Pengetahuan Wajib Pajak, Penyuluhan, Kualitas Pelayanan Pajak, dan Pemeriksaan Pajak Terhadap Kepatuhan Wajib Pajak Badan di Kota Padang.

Rahayu, Sri dan Ita Salsalina Lingga. 2009. Pengaruh Modernisasi Sistem Administrasif Perpajakan Terhadap Kepatuhan Wajib Pajak. Jurnal Akuntansi. Vol. 1, No 2, November 2015. Hal $119-138$.

Sarunan, dan Widya K. 2015. Pengaruh Modernisasi Sistem Administrasif Perpajakan Terhadap Kepatuhan Wajib Pajak Orang Pribadi Dan Wajib Pajak Badan Pada Kantor Pelayanan Pajak Pratama Manado. ISSN: 2303 - 1174. Jurnal EMBA. Vol. 3, No 4, 2015. Hal $518-526$.

Suyapto, Mellisa dan Mienati Somya Lasmana. 2014. Analisis Faktor-Faktor Yang Mempengaruhi Kepatuhan Wajib Pajak Badan Di Kantor Wilayah Direktorat Jenderal Pajak Jawa Timur I. Jurnal Ekonomi dan Bisnis.Jurnal Ekonomi dan bisnis. No 2. Hal $174-186$. 
Utama, I Wayan Mustika. 2012. Pengaruh Kualitas Pelayanan, Sanksi Perpajakan dan Biaya Kepatuhan Terhadap Kepatuhan Wajib Pajak. Fakultas Ekonomi Universitas Udayana. Hal 452- 470.

Utami, Tri, Siti Nurlaela dan Suhendro. 2017. Pengaruh Pengetahuan Tentang Penggunaan EBilling, Kualitas Sistem, Kepatuhan Membayar Pajak, Terhadap Efektivitas Pelaporan Pajak. ISSN: 2337 - 4349. Seminar Nasional IENACO.

Tjiptono, Fandy, 1997. Prinsip - Prinsip Total Quality Service, Yogyakarta : Andi Offset, Yogyakarta

Tologana, Evalin Yuanita dan Meily Kalalo. 2016. Pengaruh Penerapan Administrasi

Perpajakan Modern Terhadap Kepatuhan Wajib Pajak Orang Pribadi di Kota Manado.

Vol. 2, No 2. 